\title{
"Ceria"
}

Jurnal Program Studi Pendidikan Anak Usia Dini

ISSN 2301-9905

Volume 10, No 2 Januari 2022

Fakultas Keguruan dan Ilmu Pendidikan - Universitas Muhammadiyah Tangerang

\section{PENGEMBANGAN GAME INTERAKTIF HURUF HIJAIYAH}

\section{BERBASIS ANDROID}

\author{
${ }^{1}$ Angger Prima Widhiasih, ${ }^{2}$ Miftahul Zannah \\ ${ }^{1,2}$ Program Studi Pendidikan Guru Pendidikan Anak Usia Dini, Fakultas Keguruan Dan \\ IImu Pendidikan, Universitas Muhammadiyah Tangerang \\ Email : ${ }^{1}$ prima.widhiasih@gmail.com, 2 miftahulzannah@gmail.com
}

\begin{abstract}
Abstrak
Penelitian ini bertujuan untuk mengetahui cara pengembangan dan kelayakan media pembelajaran game interaktif huruf hijaiyah usia 4-5 tahun berbasis android. Jenis penelitian dan pengembangan atau Research and Development (R\&D) ini menggunakan model S. Thiagarajan, Dorothy S. Semmel, dan Melvyn I. Semmel 4 tahap pengembangan. Data yang diperoleh akan dianalisis dengan menggunakan skala likert. Hasil uji kelayakan media pembelajaran game interaktif menunjukkan media "sangat layak" berdasarkan hasil validasi ahli media 1 yaitu sebesar 100\%, ahli media 2 96\% dan ahli materi 96\%. Respon tanggapan guru menunjukkan media "sangat baik" dengan presentase 86,7\%. Selanjutnya respon peserta didik disekolah menunjukan media pembelajaran "sangat menarik" yang menunjukkan hasil berkembang sangat baik. Berdasarkan perolehan hasil tersebut dapat disimpulkan media pembelajaran game interaktif berbasis android sangat layak digunakan sebagai media pembelajaran pengenalan huruf hijaiyah pada peserta didik usia 4-5 tahun.
\end{abstract}

Kata kunci: Huruf Hijaiyah, Game Interaktif, Android

\section{Pengantar}

Pendidikan merupakan sebagai salah satu jembatan untuk mewujudkan cita - cita nasional yaitu mencerdaskan kehidupan bangsa, karena pendidikan memberikan bimbingan dan arahan kepada anak didik untuk mencapai tingkat kedewasaan, berkembangnya kemampuan Anak Usia Dini untuk menciptakan kemandirian dan 
kesejahteraan pada anak, supaya mampu mandiri dan menampilkan individualitasnya sebagai manusia terdidik.

Pembelajaran pada masa pandemi sekarang ini anak dihadapkan pada teknologi yang ada di lingkungan sekitar, diantaranya adalah handphone, televisi, dan komputer. Teknologi yang akan menjadi alat sebagai media yang efektif dan menyenangkan untuk anak usia dini, dapat membantu agar dalam pembelajaran anak merasa tidak bosan. Teknologi di masa kini memberikan pengaruh yang sangat besar terhadap perkembangan anak. Tidak jarang ditemukan anak usia sekolah dasar sudah mahir bermain game di perangkat seluler. Permainan interaktif pada android dengan tema pendidikan angka dan huruf hijaiyah, untuk mengenalkannya kepada anak usia dini dengan cara yang menyenangkan dan mudah dipahami (Naufaliawan, Isnanto, and Windasari 2015). Dengan adanya media yang berbeda dari biasanya anak akan lebih tertarik untuk mempelajari huruf-huruf hijaiyah, karena anak akan merasakan suasana pembelajaran tersebut seolaholah menjadi kegiatan bermain, sehingga anak akan lebih mudah dalam menerima materi pelajaran Bahasa Arab.

Game edukasi merupakan sebuah permainan dibuat dan dirancang khusus untuk dijadikan sebuah media yang digunakan untuk mengajar orang melalui materi yang berisikan suara, teks, gambar, video, dan animasi, yang pokok materinya membahas suatu subjek tertentu, yang memiliki tujuan untuk dapat memperluas konsep, memberikan pemahaman yang lebih baik dari materi yang mengajarkan sebuah peristiwa sejarah maupun budaya (Supriadi 2018). Game edukasi pada handphone atau aplikasi android yang sering anak mainkan kebanyakan berupa permainan building block, permainan figur makhluk hidup, maupun permainan yang melibatkan pengenalan objek sehari-hari. Seringkali produsen permainan terus memproduksi jenis permainan yang sama dengan modifikasi yang minim.

Musa, 2012 Huruf Hijaiyah adalah huruf arab yang berada di dalam Al-Quran yang dipelajari oleh orang muslim. Jumlah Huruf Hijaiyah yang umumnya diketahui total 30

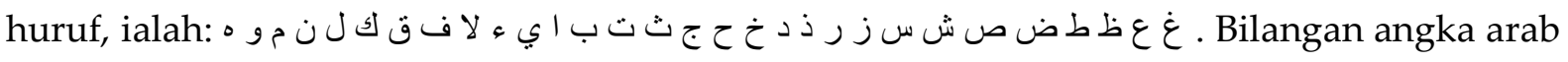
ialah penyebutan sepuluh digit angka yaitu $0,1,2,3,4,5,6,7,8,9$ yang menggunakan

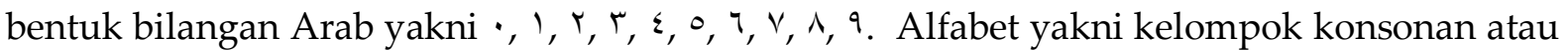
aksara yang terstruktur berlandaskan rangkaian yang normal atau sistem aksara yang 
melambangkan pengucapan bahasa yang dipakai untuk mencantumkan kata-kata atau bahasa yang terdiri dari A sampai Z. Mempelajari huruf hijaiyah merupakan suatu langkah awal untuk membaca kitab suci Al-Qur'an. Strategi yang baik akan sangat diperlukan dalam kemampuan belajar membaca huruf hijaiyah, oleh karena itu pemilihan metode atau media pembelajaran yang tepat mempunyai andil besar dalam meningkatkan kemampuan membaca huruf hijaiyah anak. Aplikasi pembelajaran dapat dipasang di mobile sehingga penggunaannya dapat dilakukan di mana saja dan kapan saja tidak terbatas akan ruang dan waktu (Muyaroah \& Fajartia, 2017) (Devita, Andryana, and Hidayatullah 2020). Namun kenyataan dalam pembelajaran pengenalan huruf hijaiyah anak masih banyak yang kurang tertarik karena media yang digunakan tidak kreatif seperti menirukan, mengulang, menarik garis, menebalkan huruf dan menyalin kembali huruf/kata/kalimat.

Pada dasarnya, daya ingat anak usia dini adalah daya ingat yang sangat mendasar. Penalaran anak usia dini masih sangat sederhana dan sangat peka terhadap wujud benda dan warna. Oleh karena itu dalam usaha mengenalkan huruf hijaiyah pada anak usia dini tidak boleh menuntut penalaran anak akan huruf demi huruf, melainkan penalaran hafalan anak terhadap huruf hijaiyah itu dengan variasi bentuk dan warna yang mudah meresap ke dalam memori ingatan mereka. Dengan demikian, dalam usaha mengenalkan huruf hijaiyah pada anak usia dini, salah satu metode yang dapat dilaksanakan adalah dengan sistem operasi android yang didalam nya menggunakan media gambar-gambar yang bervariasi, baik gambar foto, gambar cetak atau sejenisnya.

Fakta dilapangan adalah pembelajaran saat ini berubah menjadi daring, keterlibatan anak lebih banyak menggunakan teknologi dengan menonton ataupun bermain game. Oleh karena itu, peneliti ingin menyediakan sarana game interaktif, sehingga saat anak bermain tetap memberikan pengetahuan pengenalan huruf hijaiyah.

Berdasarkan uraian dan permasalahan di atas, penulis tertarik untuk merancang dan membangun game interaktif menggunakan system operasi android yang dapat digunakan untuk melakukan pengenalan Huruf Hijaiyah. Konsep dari aplikasi ini nantinya selain untuk proses pengenalan Huruf Hijaiyah, ketika dijalankan aplikasi ini akan mengenali Huruf Hijayah berdasarkan pola marker nya, apabila dikenali maka aplikasi ini akan memberikan informasi tambahan berupa 3D, teks dan audio pelafalan dari Huruf Hijaiyah tersebut. Dengan adanya aplikasi ini diharapkan dapat menjadi media yang dapat 
membantu pengenalan Huruf Hijayah terkhusus bagi anak-anak yang mulai belajar mengaji.

\section{Metode}

Metode penelitian yang digunakan dalam penelitian ini adalah penelitian dan pengembangan (Research and Development). Produk yang dikembangkan dalam penelitian ini adalah game interaktif berbasis android. Model pengembangan yang digunakan dalam penelitian ini adalah model 4D yang dikemukakan oleh Thiagarajan, Semmel dan Semmel (1974) dimana terdapat 4 tahapan yaitu, (1) tahap pendefinisian, (2) tahap perencanaan, (3) tahap pengembangan, dan (4) tahap penyebaran.

Instrument penelitian yang digunakan dalam penelitian ini adalah angket. Angket digunakan untuk mengetahui kualitas permainan yang telah dikembangkan. Pada penilaian angket menggunakan rumus skala likert. Rumus yang digunakan adalah:

(Yusuf Sukman 2017)

$$
\mathrm{P}=\frac{\text { Jumlah skor hasil pengumpulan data }}{\text { Skor Kriteria }} \times 100 \%
$$

Ket :

$$
\mathrm{P}=\text { Presentase }(\%)
$$

Tolak ukur yang terdapat dalam angket terdapat dalam tabel 1 di bawah ini.

\begin{tabular}{|c|c|c|}
\hline Presentase & Keterangan & Angka \\
\hline $81-100 \%$ & Sangat setuju & 5 \\
\hline $61-80 \%$ & Setuju & 4 \\
\hline $41-60 \%$ & Cukup Baik & 3 \\
\hline $21-40 \%$ & Tidak setuju & 2 \\
\hline$<20 \%$ & Sangat tidak setuju & 1 \\
\hline
\end{tabular}

\section{Hasil dan Pembahasan}

\section{Pengembangan Game Interaktif Huruf Hijaiyah Berbasis Android}

\section{A. Hasil}

Berikut ini system aplikasi dimana pengguna mampu menggunakan aplikasi game interaktif huruf hijaiyah berbasis android untuk belajar mengenal huruf hijaiyah dengan baik.

a. Tampilan Menu Utama Game Interaktif 
Pada tampilan ini sangat penting untuk sebuah permainan, karena mewakilkan pilihan untuk mulai belajar dan bermain.

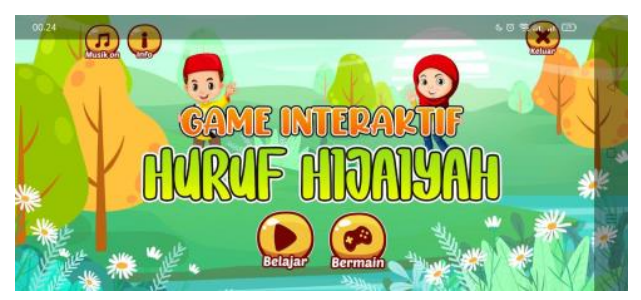

Gambar 1. Tampilan Menu Utama

b. Tampilan Menu Info

Pada tampilan menu info terdapat profil peneliti. Berikut adalah tampilan menu info game interaktif.

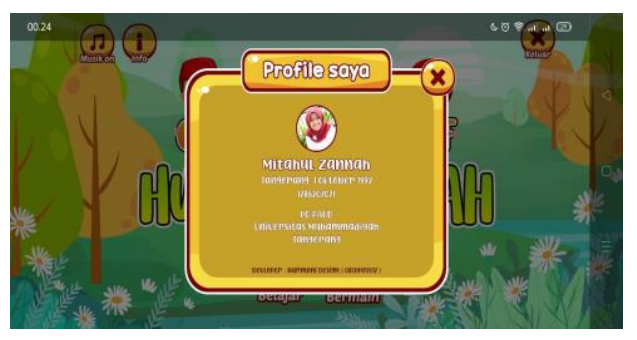

Gambar 2. Tampilan Menu Info

c. Tampillan Menu Belajar

Pada tampilan menu belajar terdapat pengenalan huruf hijaiyah dalam bentuk suara dan tulisan serta dapat ditampilkan secara keselurahan. Berikut adalah tampilan menu belajar pada game interaktif.

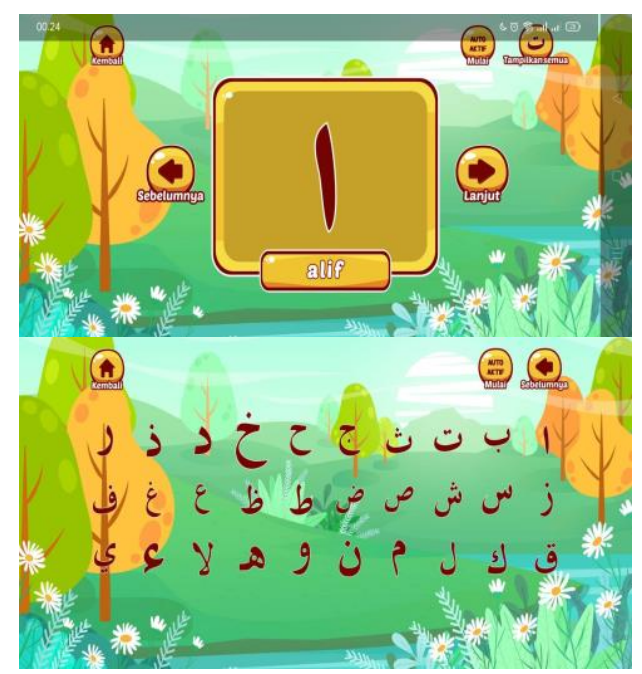

Gambar 3. Tampilan Menu Belajar

d. Tampilan Menu Bermain

Pada tampilan menu bermain terdapat beberapa permainan seperti menyusun huruf, menebak gambar dan puzzle yang sangat mudah di operasikan. Berikut adalah tampilan menu bermain pada game interaktif. 


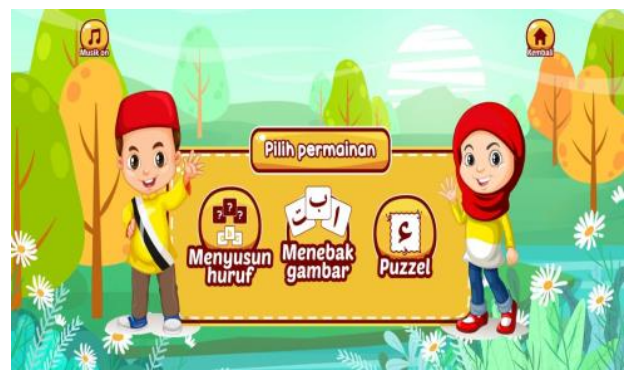

Gambar 4. Tampilan Menu Bermain

e. Tampilan Menu Permainan Menyusun Huruf

Pada tampilan menu permainan menyusun huruf ini terdapat gambar huruf hijaiyah dan kata-kata yang harus disusun dengan benar dan tepat, ketika dapat menjawab dengan benar akan muncul menu melanjutkan. Berikut adalah tampilan menu permainan menyusun huruf pada game interaktif.
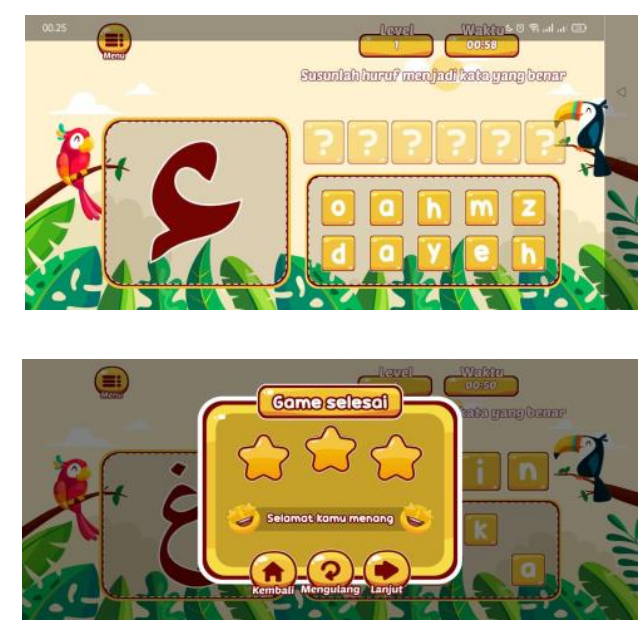

Gambar 5. Tampilan Menu Permainan Menyusun Huruf

f. Tampilan Menu Permainan Menebak Gambar

Pada tampilan menu permainan menebak gambar ini terdapat gambar huruf hijaiyah dan kata-kata yang harus dipilih secara benar. Berikut adalah tampilan menu permainan menebak gambar pada game interaktif.

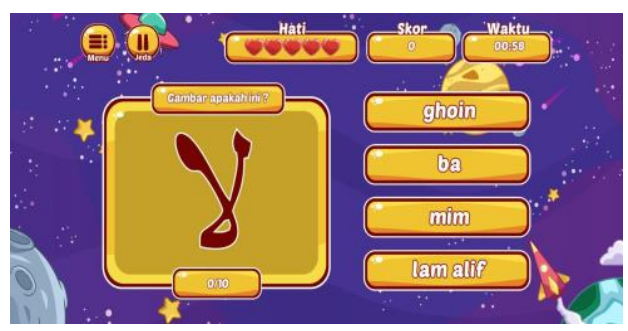

Gambar 6. Tampilan Menu Permainan Menebak Gambar

g. Tampilan Menu Permainan Puzzle

Pada tampilan menu permainan puzzle ini terdapat gambar huruf hijaiyah yang harus dicocokkan dengan huruf hijaiyah yang sudah ditentukan, ketika waktu yang sudah ditentukan selesai makan akan muncul menu tampilan game selesai dan 
terdapat skor didalamnya. Berikut adalah tampilan menu permainan puzzle pada game interaktif.

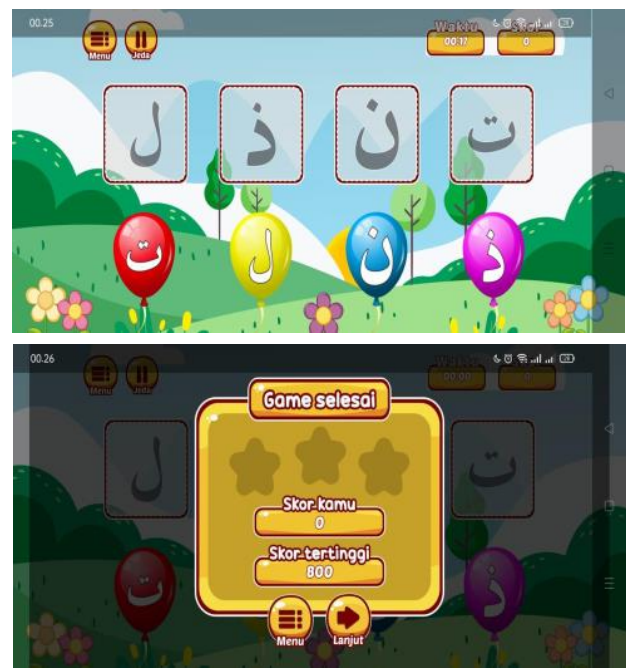

Gambar 7. Tampilan Menu Permainan Puzzle

h. Tampilan Menu Keluar

Pada tampilan menu keluar terdapat pilihan yakin ingin keluar dari game tersebut atau tidak. Berikut adalah tampilan menu keluar pada game interaktif.

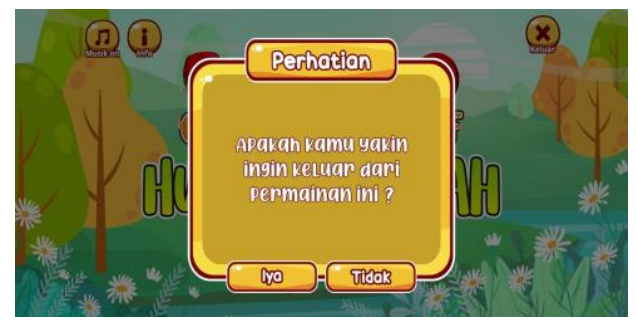

Gambar 8. Tampilan Menu Keluar

\section{B. Pembahasan}

Proses pengembangan game interaktif berbasis android dilakukan melalui beberapa tahapan yaitu: 1) Pendefinisian, bertujuan mengetahui kebutuhan pelajaran di lapangan. 2) Perancangan, merupakan tahap merancang draft awal yang akan digunakan. 3) Pengembangan, untuk menghasilkan draft game interaktif yang telah direvisi berdasarkan masukan dari para ahli dan data yang diperoleh dari uji coba. Draft II diperoleh setelah melakukan tahap validasi ahli dan data yang diperoleh dari uji coba. 4) Penyebaran, tahapan akhir dari pengembangan. Tujuannya untuk mendeskripsikan keterpakaian game interaktif pada anak usia dini.

Uji coba game interaktif ini dilakukan kepada 4 subjek yaitu ahli materi, ahli media, guru, dan siswa. Data hasil validasi ahli media terhadap permainan interaktif berbasis teknologi disajikan pada tabel 2.

Tabel 2. Hasil validasi ahli media

\begin{tabular}{|c|c|c|c|c|}
\hline No & Validator & $\begin{array}{c}\text { Skor yang } \\
\text { diperoleh }\end{array}$ & $\begin{array}{c}\text { Skor } \\
\text { Max }\end{array}$ & Presentase \\
\hline 1 & I & 50 & 50 & $100 \%$ \\
\hline 2 & II & 48 & 50 & $96 \%$ \\
\hline
\end{tabular}


Berdasarkan hasil validasi ahli media 1 memperoleh jumlah skor 100\%. Dan berdasarkan validasi ahli media 2 memperoleh jumlah skor $96 \%$. Berdasarkan pedoman data kuantitatif ke kualitatif termasuk dalam kategori "sangat baik".

Data hasil validasi ahli materi terhadap game interaktif berbasis android disajikan pada tabel 3.

Tabel 3. Hasil validasi ahli materi

\begin{tabular}{|c|c|c|c|c|}
\hline No & Validator & $\begin{array}{c}\text { Skor yang } \\
\text { diperoleh }\end{array}$ & $\begin{array}{c}\text { Skor } \\
\text { Max }\end{array}$ & Presentase \\
\hline 1 & I & 48 & 50 & $96 \%$ \\
\hline
\end{tabular}

Hasil validasi ahli materi memperoleh jumlah skor $96 \%$. Berdasarkan pedoman data kuantitatif ke kualitatif termasuk dalam kategori "sangat baik".

Setelah melakukan validasi dengan ahli media dan ahli materi, game interaktif yang telah dikembangkan akan diujicobakan kepada pendidik (guru). Uji coba kepada pendidik dilakukan setelah melakukan perbaikan berdasarkan saran dan komentar validator ahli. Pelaksanaan uji coba guru dimulai dari mempresentasikan game interaktif, kemudian meminta guru untuk memainkan game interaktif tersebut dan kemudian menilainya dengan mengisi kuesioner yang telah disediakan. Hasil uji coba guru disajikan dalam tabel 4 .

Tabel 4. Hasil penilaian guru

\begin{tabular}{|c|c|c|c|}
\hline No & Responden & $\begin{array}{c}\text { Skor yang } \\
\text { diperoleh }\end{array}$ & Presentase \\
\hline 1 & 20 & 867 & $86,7 \%$ \\
\hline
\end{tabular}

Dalam hasil uji coba guru secara keseluruhan memperoleh jumlah skor $86,7 \%$, berdasarkan pedoman data kuantitatif ke kualitatif termasuk dalam kategori "sangat baik".

Setelah melakukan uji coba guru, Perbaikan dilakukan untuk lebih menyempurnakan permainan. Pelaksanaan Hasil perbaikan akan diuji cobakan pada kelompok kecil. Responden uji coba kelompok kecil terdiri dari 20 siswa. Hasil uji coba kelompok kecil disajikan dalam tabel 5.

Tabel 5. Hasil uji coba kelompok kecil

\begin{tabular}{|c|l|c|c|c|}
\hline No & Responden & $\begin{array}{c}\text { Skor yang } \\
\text { diperoleh }\end{array}$ & $\begin{array}{c}\text { Skor } \\
\text { Max }\end{array}$ & Presentase \\
\hline 1 & Siswa 1 & 45 & 50 & $90 \%$ \\
\hline 2 & Siswa 2 & 43 & 50 & $86 \%$ \\
\hline 3 & Siswa 3 & 44 & 50 & $88 \%$ \\
\hline 4 & Siswa 4 & 43 & 50 & $86 \%$ \\
\hline 5 & Siswa 5 & 41 & 50 & $82 \%$ \\
\hline 6 & Siswa 6 & 43 & 50 & $86 \%$ \\
\hline 7 & Siswa 7 & 41 & 50 & $82 \%$ \\
\hline 8 & Siswa 8 & 41 & 50 & $82 \%$ \\
\hline 9 & Siswa 9 & 41 & 50 & $82 \%$ \\
\hline 10 & Siswa 10 & 47 & 50 & $94 \%$ \\
\hline 11 & Siswa 11 & 45 & 50 & $95 \%$ \\
\hline 12 & Siswa 12 & 43 & 50 & $86 \%$ \\
\hline 13 & Siswa 13 & 45 & 50 & $90 \%$ \\
\hline
\end{tabular}




\begin{tabular}{|l|l|l|l|l|}
\hline 14 & Siswa 14 & 43 & 50 & $86 \%$ \\
\hline 15 & Siswa 15 & 45 & 50 & $90 \%$ \\
\hline 16 & Siswa 16 & 46 & 50 & $92 \%$ \\
\hline 17 & Siswa 17 & 45 & 50 & $90 \%$ \\
\hline 18 & Siswa 18 & 40 & 50 & $80 \%$ \\
\hline 19 & Siswa 19 & 42 & 50 & $84 \%$ \\
\hline 20 & Siswa 20 & 44 & 50 & $88 \%$ \\
\hline
\end{tabular}

Dalam uji coba lapangan yang dilakukan pada 20 anak TK A TK Al Ikhlas memperoleh jumlah skor $87 \%$, berdasarkan pedoman data kuantitatif ke kualitatif termasuk dalam kategori "sangat baik".

\section{Kesimpulan}

Berdasarkan uraian sebelumnya, maka dapat diambil kesimpulan dari penelitian ini ialah melalui aplikasi game interaktif huruf hijaiyah ini pemahaman anak dalam mengenal huruf hijaiyah lebih baik, hal ini dikarenakan anak belajar melalui seluruh inderanya dalam permainan ini anak melihat simbol huruf hijaiyah dan mendengar suara saat memainkan game. Perasaan yang gembira, menciptakan pembelajaran yang lebih efektif dan bermakna positif dalam penggunaan teknologi pada masa pandemi. Diharapkan pendidik anak usia dini mampu merancang dan membuat game interaktif dengan ragam teknologi guna terciptanya pembelajaran yang bermakna dan menyenangkan.

\section{DAFTAR PUSTAKA}

Angger Prima Widhiasih, Sandra Yunita. 2021. "Pengembangan Permainan Interaktif Berbasis Teknologi Untuk Anak Usia Dini." Jurnal Program Studi Pendidikan Anak Usia Dini 10(1):1-11.

Anon. 2003. "Undang-Undang Republik Indonesia Nomor 20 Tahun 2003." Kaos GL Dergisi (76):147-73.

Devita, Maurizka Zahra, Septi Andryana, and Deny Hidayatullah. 2020. “Augmented Reality Pengenalan Huruf Dan Angka Arab Menggunakan Metode Marker Based Tracking Berbasis Android." Jurnal Media Informatika Budidarma 4(1):14. doi: 10.30865/mib.v4i1.1850.

Fathansyah. 2018. "Rancang Bangun Aplikasi Pendataan Kompensasi Bagi Mahasiswa Teknik Telekomunikasi Berbasis Android." Statistical Field Theor 53(9):1689-99.

Gunawan, Wawan. 2019. "Pengembangan Aplikasi Berbasis Android Untuk Pengenalan Huruf Hijaiyah." Jurnal Informatika 6(1):69-76. doi: 10.31311/ji.v6i1.5373.

Herlina, Mutia Nanda, Atin Fatimah, and Fahmi Fahmi. 2018. "Peningkatan Mengenal Huruf Hijaiyah Melalui Media Kartu Huruf (Penelitian Tindakan Pada Anak Usia 5-6 Tahun Di PAUD Assa'dah Serang-Banten)." Jurnal Penelitian Dan Pengembangan Pendidikan Anak Usia Dini 5(1):15. doi: 10.30870/jpppaud.v5i1.4676.

Kusniyati, Harni, and Nicky Saputra Pangondian Sitanggang. 2016. “Aplikasi Edukasi 
Budaya Toba Samosir Berbasis Android." Jurnal Teknik Informatika 9(1):9-18. doi: 10.15408/jti.v9i1.5573.

Martono, Kurniawan Teguh. 2015. “Pengembangan Game Dengan Menggunakan Game Engine Game Maker." Jurnal Sistem Komputer 5(1):23-30.

Naufaliawan, Andhika Hanifa, Rizal Isnanto, and Ike Pertiwi Windasari. 2015. "Pengembangan Permainan Untuk Pembelajaran." Jurnal Teknologi Dan Sistem Komputer (JTSiskom) UNDIP 3(2):275-81.

Pratama, Wahyu. 2014. "Game Adventure Misteri Kotak Pandora." Jurnal Telematika 7(2):13-31.

Pratiwi, Wiwik. 2017. “Konsep Bermain Pada Anak Usia Dini." Manajemen Pendidikan Islam 5:106-17.

Purwanto, Yulis, and Swaditya Rizki. 2015. "Pengembangan Bahan Ajar Berbasis Kontekstual Pada Materi Himpunan Berbantu Video Pembelajaran." AKSIOMA Journal of Mathematics Education 4(1):67-77. doi: 10.24127/ajpm.v4i1.95.

Rahmayu, Mulia, and Yunita. 2017. "Membangun Aplikasi Game Interaktif Belajar Berhitung Dan Mewarnai Untuk Anak TK." Jurnal Khatulistiwa Informatika V(1):36-41.

Shoewu, O., D. Ph, O. A. Idowu, B. Sc, S. S. Tenuche, B. Elisha, M. A. Umar, B. I. Ahmad, A. A. Sambo, Tabassam Nawaz, Saim Pervaiz, Arash Korrani, A. Ahmed, O. M. Olaniyi, J. G. Kolo, C. Durugo, and Bhrigu K Lahkar. 2016. Meningkatkan Kemampuan Membaca Huruf Hijaiyah Menggunakan Metode Tilawati Pada Anak Kelompok B6 Di Tk Aba Karangkajen Yogyakarta. Vol. 13.

Supriadi, Sugeng. 2018. "Rancangbangun Game Edukasi Pengenalan Huruf Hijaiyah Dengan Game Egine Construct 2." Buffer Informatika 3(1):1-6. doi: 10.25134/buffer.v4i1.1136.

Widiyatma, Anggi. 2016. "Pengembangan Media Interaktif Game Petualangan Berbasis Rpg-Maker Xp Untuk Pembelajaran Menulis Pantun Pada Siswa Sma Kelas XI.” 2.

Yusuf Sukman, Jayadi. 2017. "Pengembangan Media Game Edukasi Kimia Menggunakan Scratch Pada Anak Tahapan Operasional Formal." Artikel Ilmiah 4:9-15. 